\title{
SOCIAL NORMS OF SEXUAL INITIATION AMONG ADOLESCENTS AND GENDER RELATIONS ${ }^{1}$
}

\author{
Ana Luiza Vilela Borges ${ }^{2}$ \\ Eunice Nakamura ${ }^{3}$
}

Borges ALV, Nakamura E. Social norms of sexual initiation among adolescents and gender relations. Rev Latino-am Enfermagem 2009 janeiro-fevereiro; 17(1):94-100.

This study aimed to identify standards and expectations regarding sexual initiation of 14 to 18 year-old adolescents in Sao Paulo, SP, Brazil, using data from four focal groups conducted in 2006. Results revealed that gender issues are clearly present in participants' reports and showed to be essential in their choices about the moment, partners and contraceptive practices in the first sexual relation. Adolescents are subordinated to gender roles, traditionally attributed to male and female genders, i.e. the notion that sex is an uncontrolled instinct for boys, and intrinsically and closely associated to love and desire for girls. Adolescents also play a preponderant role in the perpetuation of these values within the group they live in.

DESCRIPTORS: adolescent health; sexual and reproductive health; gender and health

\section{NORMAS SOCIALES DE INICIACIÓN SEXUAL ENTRE ADOLESCENTES Y RELACIONES DE GÉNERO}

Con el objetivo de identificar las normas y expectativas sociales que se encuentran en la iniciación sexual, fueron estudiados cuatro grupos de adolescentes entre 14 y 18 años de edad, en 2.006, en la ciudad de San Pablo, Brasil. Los datos mostraron que las cuestiones de género están claramente presentes en los discursos de los entrevistados y se mostraron fundamentales en las elecciones sobre: el momento, el compañero y las prácticas contraceptivas que se encuentran en la vivencia de la primera relación sexual. Los adolescentes están subordinados a los papeles de género, tradicionalmente atribuidos a los hombres y a las mujeres, y al concepto de que el sexo es un instinto físico e incontrolable entre los muchachos, y a la intrínseca relación entre el amor, el deseo y el sexo entre las muchachas; estas percepciones tienen también un papel preponderante para mantener estos valores en el grupo en que viven.

DESCRIPTORES: salud del adolescente; salud sexual y reproductiva; género y salud

\section{NORMAS SOCIAIS DE INICIAÇÃO SEXUAL ENTRE ADOLESCENTES E RELAÇÕES DE GÊNERO}

Com o objetivo de identificar normas e expectativas sociais que cercam a iniciação sexual, foram estudados quatro grupos focais com adolescentes de 14 a 18 anos de idade, em 2006, na cidade de São Paulo, Brasil. Os dados mostraram que as questões de gênero estão claramente presentes nos discursos dos entrevistados e mostram-se fundamentais nas escolhas sobre o momento, as parcerias e as práticas contraceptivas que circundam a vivência da primeira relação sexual. Os adolescentes tanto estão subordinados aos papéis de gênero tradicionalmente atribuídos aos homens e mulheres, como a concepção de que o sexo é um instinto físico e incontrolável entre os garotos e a intrínseca relação entre amor, desejo e sexo entre as garotas, quanto têm papel preponderante para a manutenção de tais valores no grupo em que vivem.

DESCRITORES: saúde do adolescente; saúde sexual e reprodutiva; gênero e saúde

Escola de Enfermagem da Universidade de São Paulo, Brazil: ${ }^{1}$ This research was supported by FAPESP, Process 05/55428-9; ${ }^{2}$ Ph.D. in Public Health, Faculty, e-mail: alvilela@usp.br; ${ }^{3}$ Ph.D. in Anthropoly, Scholarship holder PRODOC/CAPES, e-mail: eunice_nakamura@hotmail.com. 


\section{INTRODUCTION}

The adolescence period is of great relevance for the public health area, especially in terms of sexual and reproductive health, because this is the phase when sexual practices, among which sexual initiation is highlighted, assume a specific character. Sexual initiation definitely places individuals in important contexts of vulnerability to sexually transmitted diseases (STD and AIDS), non-planned pregnancies and abortions. Thus, it is important to learn their motivations, contexts in which they occur and their implications for health.

One of the aspects that determine choices regarding the moment, partner and context in which it occurs is related to peer pressure. Hence, sexual initiation for boys is a way to express the process of becoming a man, the consolidation of masculinity, which can only be achieved among a group of equals. Therefore, "having the first sexual experience is not an automatic guarantee of a new status. Peers' acknowledgment is necessary because it confers legitimacy to the passage ${ }^{\prime \prime(1)}$. A code of conduct was observed, prescribing that, at a certain moment, virginity becomes a weight in adolescents' lives and operates as an element of pressure ${ }^{(2)}$.

Sexual initiation can be encouraged, among others, due to the diffusion of the sexual behavior model dictated by peers, molded by the meaning culturally attributed to sexuality, in which men's role is not to resist to sexual impulse and women's role is to control their impulse, ratifying gender relations, present in the sexual initiation scenario ${ }^{(1)}$.

Differences in men's and women's sexual initiation are well described in population studies that analyze data through the gender variable because, most of the times, men's sexual initiation occurs earlier than women's ${ }^{(2-3)}$. Nevertheless, studies that adopt gender relations as a category of analysis picture the diversity and complexity of individuals' sexual trajectories in a better way. The gender perspective recommends that differences between genders should not be naturalized, but considered as a consequence of a social and cultural construction of what it means to be a man and what it means to be a woman, hierarchies and relation of power in each time, space and social group ${ }^{(1)}$.

Gender issues have been considered essential in choices that surround the first sexual relation, because "the feeling of 'giving themselves' is unanimous among women in relation to the sexual act, conferring it value, that is, virginity is something "rare". At the same time as there is a desire to discover, the need for "self preservation" is imposed. The male experience, on the other hand, is translated into two attitudes: first, sexual performance is seen as a gain, supporting the power of masculinity, and second, it is definitely a romantic attitude in which men seek to 'give themselves" at the right moment to the right partner" $^{\prime(4)}$

This study assumes that men and women have different motivations for engaging in sexual life, which are the result of the construction of their identities based on gender relations. It cannot be ignored that adolescents are inserted in a friendship network that is their basic space for socialization. And their peers are not only subjected to normative norms of sexual behavior, but also reinforce these norms in their relations within the group. In this perspective, this study aimed to identify norms and social expectations surrounding sexual initiation in a group of adolescents, devised as from the particular meanings expressed in their reports.

\section{METHOD}

This qualitative study used the focal group technique with a semi-structured script. The study population was composed of 14 to 18 year-old adolescents, students from a public school in the East of Sao Paulo, SP, Brazil. Data were collected through four focus groups conducted in June 2006. Two were composed of girls (11 and eight participants) and two of boys (seven and six participants). The option to conduct groups separately by gender aimed to make participants feel at ease so as to expose their points of view without any reticence that could possibly occur in the presence of the opposite gender.

The choice of classrooms, where participants were invited to participate in the study, was the school's suggestion, so as to include younger adolescents (between 14 and 16 years old, attending the eighth grade of primary education) and older ones (between 16 and 18 years old, attending the second grade of secondary education).

The main themes used to guide discussions were: adolescents' daily life in the community they live in; affective/loving relationships in adolescence; and expectations and social norms that guide 
decisions regarding sexual relations during adolescence, grasped during adolescents' experiences with peers and family, including sexual initiation and the conception of a healthy sexual life. The authors, who played the roles of moderator and observer, conducted the groups. All interviews were recorded.

Ethical recommendations were observed according to Resolution $n^{\circ} 196 / 96$. After a explanation (in class) of the study objectives, adolescents were invited to participate in the study. Free and informed consent terms were provided on the day of the invitation to be signed by the parents of students younger than 18 years old. Written consent was obtained from participants and/or their legal guardians. The study was approved by the Research Ethics Committee at the Sao Paulo City Council.

Data analysis was based on thematic content analysis $^{(5)}$. The more relevant themes expressed in the adolescents' reports were identified, associated both to their perception and behavior regarding expectations and potential pressure exerted by their socio-cultural group related to the first sexual relation.

\section{RESULTS AND DISCUSSION}

The analysis of focal groups allowed identifying some differences between genders that affect adolescents' daily life, also essential in the orientation of their sexual behavior. The highlighted themes were: 1 ) expectations in relation to the opposite gender; 2) sexual initiation; 3) expectations and control of family, neighbors and peers and 4) sexual initiation and health.

Expectations in relation to the opposite gender

Adolescents were encouraged to discuss how they saw and how they would like to be seen by the opposite gender. Reports revealed that men and women have different expectations in relation to the other, which shows disagreement in the social roles they will eventually play. Thus, girls expect boys to be responsible, respectful and committed. For girls, being respected and valued, that is, becoming girlfriends and not only "flirtation" is what is at stake.
Finding a boy, especially at school, who respects you... one who sees you and says like 'wow this girl is so nice, good girl' ... not 'this one, she's so naughty'... you know? (F4*').

Boys also expect girls to be serious in relation to affective relationships and sex issues, especially in terms of fidelity. Virginity does not appear as the central objective, but monogamy and loyalty do. That is, the essential issue seems to be the preservation of male honor and not the female behavior per se, because for boys, female fidelity is more important that virginity ${ }^{(6)}$.

As long as they don't cheat, aren't unfaithful to their husbands [what is expected from girls] (M3).

Adolescents are fully aware of social expectations regarding their behavior and feel responsible for the image others might have of their attitudes. Thus, some behaviors like restricting the number of boyfriends and sexual partners, as well as resisting boys' sexual overtures, might result from the attempt to maintain social valorization.

I think like: it's the girl who has to demand respect (F2).

Sexual Initiation

The decision of men and women regarding sexual initiation is based on a well-defined criterion: the right moment. The definition of this criterion, however, differs according to gender.

Idealization of the first sexual partner: trust to give oneself

For women, the right moment for the first sexual relation consists of trusting the partner, which is probably more important than love. Trust includes the partner's respect: he should neither talk to friends about the sexual relation - which would make the virginity issue leave the private scope and become public, putting girl's moral at risk - nor even disappear after the conquest, confirming the female desire of deepening the relationship in a more serious commitment $^{(4)}$.

So I think there's the right moment, you have to choose your moment, to see when you're ready, have to trust the other, know the guy first, see if he is alright, if he's not going to kiss and tell... 'cause otherwise you stay with the guy today and tomorrow the whole neighborhood will know (F9).

\footnotetext{
${ }^{*} \mathrm{~F}$ refers to the reports of female adolescents and $\mathrm{M}$ to reports of male adolescents.
} 
Trustiness is also important because virginity can be seen as a gift and it is, in a certain way, well kept. In other words, for girls, "the first sexual experience is understood in terms of 'giving themselves', whose legitimacy occurs in a consolidated affective relation (dating), concretized at the moment the partner is introduced to the family, after which he asks permission to date the $\operatorname{girl}^{\prime \prime(6)}$.

Sexual initiation as a ticket to the adult world

Among adolescents, the right moment to be sexually initiated also includes the stage in life in which girls feel mature. Maturity can be signalized by insertion in the job market and consequent financial autonomy, and also by age, so one can assume potential consequences of sexual life like pregnancy, partner's abandonment or even negative evaluation of their behavior.

In my opinion, I think that, when I get a job, when I'm independent, then yeah, it'll be time to do whatever I want...(F14).

Reports described in studies that used indepth interviews indicate that, for girls, sexual initiation puts them as authors of their acts, requiring responsible attitudes, decision making and, consequently, responsibility for their actions, which definitely include them in a more adult universe ${ }^{(1,4)}$.

Playing games in dating: resisting or giving in?

Another issue reported as motivation to initiate sexual relations is the pressure exerted by boyfriends. To give in may mean the assurance of having a boyfriend around and preventing him from going to look for other women who may satisfy his sexual needs. Among girls, there is a disseminated idea that men's need for sex is uncontrollable.

There're girls who have sex only because the boyfriend wants it (F5).

There're no guys who'd wait two months to have $\operatorname{sex} \ldots(\mathrm{F} 6)$.

Anyway, girls are the ones who decide when the first time will be and, in this game, there is an intense and constant movement of resistance and insistence, in which girls are constantly weighing the pros and cons of sexual initiation. There is also a fragile balance, faced by girls, between the resistance rule and risking to lose their partner ${ }^{(7)}$. In this perspective, the "dilemma between giving in or not, or yet, giving in to what point, is oftentimes weighed under the perspective of a sexual market where 'easy' women are abundant" ${ }^{\prime(7)}$. As it is up to the woman to determine the rhythm and dynamics of the relationship ${ }^{(6)}$, refusal is generally based on subterfuges to deny or postpone initiation and even boys fully understand the alleged reasons and confidently present the differences between men and women regarding their sexual nature. The male sexual need was understood in this study as more frequent and intense than the female, in the same way it was described in other studies carried out with low-income adolescent groups ${ }^{(1,7-8)}$.

For men, it can be anytime. It's different for women, it's 'today I'm not in the mood, I'm tired, I have a headache (M8).

Sexual initiation before marriage is inevitable

Reports are clear that there's no way to keep [female] virginity until marriage (F4). Thus, the issue is related to whom the girl will have her first sexual relation with, since losing virginity is inevitable. Changes in current social rules that dictate affective relationships among adolescents allow for greater parental tolerance and sexual relations dissociated of marriage but it does not mean that there are no moral classifications regarding female behavior. "A certain discretion, sexual relations subordinated to an affective bond and non-abusive multiplicity of sexual partners are still the rules to evaluate female honor among youngsters ${ }^{\prime \prime}(9)$.

I think it's beautiful to marry virgin, don't know if I'll do it, because I guess it's really hard to do it, but I think it's essential to marry virgin (F12).

Thus, losing virginity is not commonplace. Its social value has somewhat diminished, however, women still take it into high account and men also give it attention. There is currently another perspective of virginity, however, in which it is considered a burden one has to get rid of ${ }^{(10)}$.

Even virgin girls tell they're not virgin, just to brag (M6).

Even though women are initiating their sexual lives increasingly earlier and the initiation age is closer to men's ${ }^{(2)}$, their motivations for sexual engagement still meet gender roles traditionally attributed to women, like love, romance and commitment to induce sexual practice. It has to be taken into account that the study population is composed of urban adolescents who live in a large city, so perhaps these results may not be generalized to adolescents who live in small towns or in rural communities. 
Anytime is time

The right moment for boys' sexual initiation is based on the fact that male sexual needs are perceived as stronger and out of control ${ }^{(8)}$. Thus, the conception of the right moment is anytime is time (M11). Oftentimes boys feel compelled to have sexual relations, even if they do not feel ready or have desire to do it because they do not feel they have the right to say "no". Even the choice of a partner is denied if the boy is seduced. For this reason, male virginity is considered a weakness, since constant availability for sex is attributed to them. Because sex, for men, is viewed as an instinct, it naturally explains why men cannot deny it. The fear that their refusal becomes public is the social reason not to refuse $\mathrm{it}^{(7)}$. Thus, much more men than women have reported feeling compelled to maintain sexual relations ${ }^{(7)}$.

This is the time; there is no right time for men [to have the first sexual relation] (M13).

The female group corroborates with the perpetuation of social pressure when they emphasize that men who stay virgin must have some kind of problem, otherwise they would already have found a sexual partner. This observation evidences that the choice regarding one's sexual initiation, or other areas of sexuality, is not exclusively individual, but socially and culturally determined.

Virgin guys are always unattractive...(F8).

Control and expectations of family, community and peers

The clear social control, which adolescents are generally subject to, is highlighted. It includes the observation of their behavior and later report of their parents' judgment. The intensity of this control seems to be the same for both genders, that is, men and women are subject to gossip and criticism as a consequence of their clothes, friendship, physical appearance, time of arriving and leaving home, among others. However, requirements used to establish and label adolescents were very diverse in terms of gender, that is, gender conceptions also form the basis of the mechanism that operates in the representations of this group who lives close to adolescents.

For girls, control means watching their behavior and evaluating their moral conduct. For boys, the concern is related to drugs consumption and trafficking, or yet the possibility of not getting a job.
Yeah, [if] you gain weight...you're pregnant...if you have large breasts, it's milk... it's like this, where I live it's like this (F12).

You get home late and people already think you're using drugs...(M8).

We observe that parents control their daughters' social behavior ${ }^{(11)}$, which can be indirectly done when parents try to dialog with them, aiming to stay informed about events in the sexuality area and love relationships, especially in relation to virginity. It can also be directed, when parents decide whom they will be friends with, impose time to get back home, especially when they go out with boyfriends, and advise on the level of physical intimacy established with partners. Parental control in relation to male children is mainly exerted to assure the adolescent will become a hard worker and responsible person, much more than with regard to their sexual behavior.

My mom would talk too much, like pay attention to where he puts his hands, watch what the guy is doing, if he's fooling around (F17).

Man, the thing they [parents] want the most is 'have you lost it [virginity], tell me...' (F9).

In the sexual initiation scenario, the control peers exert on women is mainly linked to the possibility of having other sexual partners. In this case, women are belittled as having passed through the hands of too many men, which is not the case for men.

Yeah, if [the girl] dates for a week with one and then with another... Then she is badmouthed (M2).

Sexual initiation before marriage is acceptable among women, as long as it happens within committed relationships with affective bonds and does not include too many sexual partners. This is possibly so because, according to the studied group's conception, female desire emerges only from a loving involvement with a partner, that is, desire originates from love, not instinct, like what happens for men ${ }^{(12)}$. Girls who break the triangle of love, desire and sex are, in fact, deviating from a path that women would naturally follow in their sexual experience.

Pressure to initiate sexual life in case of men comes from their peers: boys have to lie to their friends when they are still virgin. Sexual performance is also always highlighted. Because they worry about the possibility of failing to have an erection, they tell many lies to their friends when they share their sexual experiences in order to impress them. In this perspective, the honor and masculinity of a man is measured by his sexual performance, leading to great commotion in case their performance is questioned ${ }^{(7)}$. 
If you say you're not going, people mock you (M10) [not going to have sex when a girl seduces a boy].

It is clear that parents of male adolescents do not try to postpone their sexual initiation. For them, boys can have sex with no restrictions, as long as it does not cause a problem: pregnancy. This way, parents start to encourage the use of condoms. Apparently, boys are not encouraged, at any moment, to preserve their virginity or wait for a special moment or special girl, like what happens with girls.

My father says that, as long as I use a condom, I can do it as I wish (M1).

Parents clearly play a role in the sexual initiation of their children. Differences were observed in expectations and attitudes of mothers and fathers in relation to the conduct of women and men in relation to sex ${ }^{(13)}$. Boys seem to feel freer to initiate sexual life outside marriage (parents transmit a positive idea regarding their sexual initiation), while girls sense such practice is not in agreement with their parents' wishes. These expectations were statistically associated to the beginning of sexual initiation among male adolescents, indicating that focusing on the family is also important to promote adolescents' sexual and reproductive health. This idea makes even more sense if we keep in mind that there is a policy in Brazil to re-orient the focus of primary health care towards the family, which is the Family Health Program, already implemented to a greater or lesser extent in all regions of the country ${ }^{(14)}$.

Another interesting point is the strong encouragement of parents, media and health professionals to use condoms. To the contrary, a consensual aversion to it, because it takes away spontaneity and pleasure, was observed. The real dimension of this conception and its impact in the use of this contraceptive method need to be further investigated among adolescents and present a great challenge to health professionals.

There're some [friends] who already say before doing it [sexual relation], man, no condom 'cause it sucks (F5).

Initiating sexual life and health

At first sight, in the interviewees' opinion, the beginning of a healthy sexual life is closely linked to STD and AIDS prevention, that is, the use of male condoms. However, its use is restricted to the first sexual contacts, until a bond of trust is established ${ }^{(3)}$; condom is then replaced by the contraceptive pill during stable relationships. Curiously, this substitution is not isolated but accompanied by laboratory tests to detect AIDS and other STDs.

[The beginning of a healthy sexual life] is using condom, is taking an HIV test...(M8).

Despite the vulnerability which adolescents are subject to due to SDT and AIDS, the main concern is related to pregnancy. For them, avoiding pregnancy is primarily a woman's role, because they are the ones who get pregnant and should assume the consequences of this event, emphasizing the classical dichotomy between reproduction and sexuality ${ }^{(8)}$. We cannot deny that contraception is rarely equally experienced between partners, which causes consequences for the way it is seen and put in practice.

Boys are not badmouthed, why do girls always have to be badmouthed? Boys can do everything, they don't get pregnant! (F6).

Responsibility to prevent pregnancy, SDT and AIDS is somewhat self imposed, that is, adolescents feel responsible for their reproductive and sexual health and do not report any thoughts on reproductive and sexual rights as basic human rights or citizenship. This is exemplified by the fact that they were not able to list how health professionals could help them in these issues, except by the free distribution of condoms at the basic health unit, which is only a block away from the school where the research was carried out.

\section{FINAL CONSIDERATIONS}

Gender issues are present in the participants' reports and are essential in decisions that surround sexual initiation, whether they are about the moment and ideal partner or the adoption of practices that prevent pregnancy or SDT and AIDS. This way, different values - social, historical and culturally built - are attributed to this event and guide a distinct sexual initiation between men and women who, in turn, have a preponderant role in maintaining such values in the group they live in.

Reports confirm that being among peers is an important "place" of socialization for sexuality ${ }^{(12)}$. In addition, learning about sexuality is a process of personal experimentation and internalization of the group's sexual culture, which is accelerated in adolescence and youth. Learning includes the familiarization of representations, values, gender roles, rituals of interaction and practices ${ }^{(1)}$. Sexual initiation has to be understood, however, under the 
consideration that the importance of peers is transitory and such period is crucial between the progressive distancing from the family of origin and the constitution of a new one.

Reports show that sexual initiation cannot be simply understood as the first sexual intercourse, but as a route adolescents follow, not linearly, with their own rules to be respected or refused, with setbacks and advances, experimentations and choices. It is clear to what extent the participants are subject to social rules that guide sexuality - largely influenced by still current gender relations - and to what extent they reproduce these standards in their daily life, unaware of inequalities created by these representations.

It could be concluded that health professionals should understand the distance between the basic health unit and adolescents, because the latter do not fit into the traditional profile of priorities that services usually consider in their activity plan. The challenge in promoting sexual and reproductive health for adolescents is specially related to the understanding of conceptions they hold regarding the world and behaviors related to sexual life issues. These conceptions are guided by gender identities, built very early in their life, assimilated and repeated. Very few realize they are subordinated to pressure from peers and family in the area of sexual initiation.

Therefore, health approaches and interventions should take into account that adolescents have individual and singular needs, which are molded in their relations with the other, whether the other is of the same gender or not, and that these relations are strongly marked by gender imperatives.

\section{REFERENCES}

1. Heilborn ML. Construção de si, gênero e sexualidade. In: Heilborn ML. Sexualidade: o olhar das ciências sociais. Rio de Janeiro (RJ): Jorge Zahar; 1999. p. 40-58.

2. Borges ALV, Schor N. Início da vida sexual na adolescência e relações de gênero: um estudo transversal em São Paulo, Brasil, 2002. Cad Saúde Pública 2005 março-abril; $21(2): 499-507$.

3. Pirotta KCM. Intenções reprodutivas e práticas de regulação da fecundidade entre universitários. Rev Saúde Pública 2004 agosto; 38(4):495-502.

4. Rieth F. Ficar e namorar. In: Bruschini C, Hollanda HB, organizadoras. Horizontes plurais: novos estudos de gênero no Brasil. São Paulo (SP): Editora 34; 1998. p. 113-33.

5. Bardin L. Análise de conteúdo. Lisboa: Edições 70; 1977. 6. Pantoja ALN. "Ser alguém na vida": uma análise sócioantropológica da gravidez/maternidade na adolescência, em Belém do Pará, Brasil. Cad Saúde Pública 2003; 19 (Supl 2):335-43.

7. Salem T. "Homem... já viu, né?": representações sobre sexualidade e gênero entre homens da classe popular. In: Heilborn ML, organizadora. Família e sexualidade. Rio de Janeiro (RJ): Editora FGV; 2004. p.15-60.

8. Knauth DR, Heilborn ML, Bozon M, Aquino EML. Sexualidade juvenil: aportes para as políticas públicas. In: Heilborn ML, Aquino $E M L$, Bozon M, Knauth DR, organizadores. O aprendizado da sexualidade: reprodução e trajetórias sociais de jovens brasileiros. Rio de Janeiro (RJ): Garamond; 2006. p. 400-16.

9. Brandão ER. Iniciação sexual e afetiva: exercício da autonomia juvenil. In: Heilborn ML, organizadora. Família e sexualidade. Rio de Janeiro (RJ): Editora FGV; 2004. p.6386.

10. Bozon M, Heilborn ML. As carícias e as palavras: iniciação sexual no Rio de Janeiro e em Paris. Novos Estudos CEBRAP 2001 janeiro-junho; 59:111-35.

11. Gonçalves H, Knauth DR. Aproveitar a vida, juventude e gravidez. Rev Antropol 2006 julho-dezembro; 49(2): 62543.

12. Olavarría J. Desejo, prazer e poder: questões em torno da masculinidade heterossexual. In: Barbosa RM; Parker R, organizadores. Sexualidades pelo avesso: direitos, identidades e poder. Rio de Janeiro (RJ): Editora 34; 1999. p. 153-74.

13. Borges ALV, Latorre MRDO, Schor N. Fatores associados ao início da vida sexual de adolescentes matriculados em uma unidade de saúde da família da zona leste do Município de São Paulo, Brasil. Cad Saúde Pública 2007 julho; 23(7):1583-93.

14. Borges ALV, Nichiata LYI, Schor N. Conversando sobre sexo: a rede sociofamiliar como base de promoção da saúde sexual e reprodutiva de adolescentes. Rev Latino-am Enfermagem 2006 maio-junho; 14(3):422-7. 